\title{
Impact of Teacher Absenteeism on Student Achievement at Primary Level in Balochistan
}

\author{
Rukhsana $^{1} \quad$ Niamatullah $^{1 *} \quad$ Ajaz Shaheen ${ }^{1} \quad$ Nagina Gul $^{2} \quad$ Abdul Rab $^{3} \quad$ Ali Murtaza Shah ${ }^{1}$ \\ 1.Faculty of Education, Lasbela University of Agriculture, Water and Marine Sciences, LUAWMS Uthal, \\ Balochistan, Pakistan. \\ 2.Department of Management Sciences, Balochistan University of Information Technology, Engineering \& \\ Management Sciences (BUITES), Quetta, Balochistan, Pakistan. \\ 3.Faculty of Management and Social Sciences, Lasbela University of Agriculture, Water and Marine Sciences, \\ LUAWMS Uthal, Balochistan, Pakistan.
}

\begin{abstract}
The purpose of this study is to find out causes of teacher absenteeism and its impact on student achievement at the primary level in Balochistan, Pakistan. Quantitative method is used in this study. Quantitative method based on the primary data collected from five purposive selected primary schools. Participants were teachers, students, and parents of this study. The main findings of the study showed that lack of motivation and low salary are main causes of teacher absenteeism which leads students' absenteeism and affect quality education, and impact students' achievement. The study also revealed that there are also many causes of teacher absenteeism at primary level such as classroom structure, care of family members, seniority and professional standing. It is suggested that teachers should be monitored properly and awarded monetary and non-monetary incentives in order to control teacher absenteeism. This study also suggests good practices to minimize the absence and enhance students' achievement at primary level.
\end{abstract}

Keywords: Teachers, Absenteeism, Impact, Achievement, Primary School Students

DOI: $10.7176 / \mathrm{JEP} / 11-18-12$

Publication date:June 30th 2020

\section{Introduction}

Education is one of the most important investments a country can make in its people and its future. It is a powerful agent of change, and improves health and livelihoods, contributes to social stability and drives longterm economic growth. In the educational system, teachers are most integral part of the society and the important consideration is to play a crucial role in the development of the students to promote their skills (Pollac, 1997). Teacher absenteeism is considered a perpetual issue of debate and an important challenge for all sectors.

Teacher absenteeism shows in the study as any type of teacher who makes the absence from the school. Teacher absenteeism has two kinds; personal absences and professional absences. Personal absence is the absence that teacher makes for the reasons relating to personal illness, family illness, personal business, death in the family etc. As a school, district, or other government agency initiated absence from the classroom is professional absences. Teacher requires absences for meeting, scoring of student test and professional development.

When constantly teacher makes absences from school it leaves students to go unattended. Additionally, teacher absenteeism decreased the amount of practice and results in incomplete syllabus. In return it affected the lower output of students' work (Ubogu, 2004). Bray and Percy (2003) noticed that vastly and influentially teacher absenteeism impacted education system of country. Regular absenteeism negatively affected the students' achievement, spoiled the reputation of school. According to Rogers and Vegas (2009) it is clear that educational quality would be spoiled due to teacher absenteeism if students get involved in playing except doing busy work. According to Chaudhury et al. (2006), teacher absenteeism impacts the access of education and school accomplishment rates when parents did not send their children to school because of poor quality. More importantly, high absenteeism of teacher was the problem of accountability and governance that are also responsible to the poor educational progress.

\section{Statement of the Problem}

Teacher absenteeism has serious effects on student achievements. A significant number of teachers are absent from their duties on any particular working day worldwide. Teacher absenteeism is a huge problem that cuts across national boundaries and is the much bigger challenge for the developing countries as compared to developed countries.

Teacher absenteeism is a major problem in education sector and negatively impacting the financial resources of a school system, as well as it is effecting the student achievement detrimentally and disruptively. Teachers, who are more often absent from schools, has a significant impact on these students who are developing their knowledge and skills on increased pace during these years (PitKoff, 1993). When teacher is absent ten days 
from class, student performance in subjects weakens and their behavior is also affected toward the teacher, although student interest in mathematics lessons.

Regular absenteeism of teacher from school disturbs the student daily performances. Because of absenteeism problem Pakistan's place is at 113th among 120 countries, the literacy rate of country under developed countries is not well. Still educational system of Pakistan has many challenges and absenteeism is one of them it has become greater in size from many years. The education system of Pakistan is facing many troubles; literacy rate is very low is in rural areas Pakistan. Teacher absenteeism rate is high where the quality of education is decreasing and affecting the developing countries as well as developed countries. Many research studies investigated teacher absenteeism and found that it causes the student absenteeism as well as cause the obstacles in student achievements (Woods \& Montagno, 1997). Therefore, the main purpose of this study to explore the views of different stakeholders regarding the impact of teacher absenteeism on student's achievement at primary level Winder, District Lasbela. The following objectives and research question were outlined to guide the study:

\subsection{Objectives of the Study}

1. To explore the causes of teacher absenteeism in government primary school.

2. To study the impact of teacher absenteeism on students' achievement.

3. To identify the good practices that will help reducing the teacher absenteeism in school.

\subsection{Research Questions}

1. What are the causes of teacher absenteeism in government primary schools?

2. What are the impact of teacher absenteeism on student achievement?

3. How good practices will help to reduce teacher absenteeism in government primary schools?

\subsection{Significance of the Study}

The purpose of this study is to increase good practices for the process of stopping teacher absenteeism and reduce absenteeism of teachers in order to improve the quality of education in schools in winder area District Lasbela. As well, to improve the performance of students at school and in their final exam. Further the importance of this study is to identify the causes of teacher absenteeism in order to modify the behavior of teaching staff towards their job performance.

\section{Literature Review}

Teacher absenteeism is contemplated a main barrier through the worldwide organization and creates hurdles and difficulties to staff and stop them to achieve the objectives. Teacher absenteeism means excused and unexcused absency, excused absence includes sickness, funeral leave and problem of transport, while, unexcused absence is done without official reason (Walfin, 1981). A study was conducted by Bullington (2002), found that really the rate of teacher absenteeism is affecting student achievement some teachers make day of by themselves on the bases of illness while some teachers have to pay their duty and the communicable disease move to their coteachers. In result of this teacher absenteeism becomes greater and lessens the capacity of teacher's work that performs while ill (Bullington, 2002). According to Nelson and Quick (2008) teacher absenteeism is caused by the dissatisfaction of teacher job, monthly salary and lack of motivation which creates negative relationship and also affect student academic performance. Many researchers have accepted teacher absenteeism as critical issue in educational system than in any occupation.

According to Luthans and Kreitner (1985) distance from school and transportation is challenging teacher to make absent. Lots of teachers keep themselves away from school because they do not have transport facility. In rural areas, mostly teachers do not go to schools because they are aware that place is far and roads are not proper for transport that any circuit supervisor will be able to easily get to the school that is why teachers do not go to school and they excuse to not having money for fare, rain and funeral etc (Lai and Chan 2000). Lacking interest in job also causing teacher absenteeism, it was investigated that teacher obtained higher degree they mostly missed the class and use teaching as a stepping stone in life and nonprofessional teachers always find better jobs (Blau,1985). Dissatisfaction is another reason to stay away from schools; teachers who are not satisfied of their jobs they mostly make off from their work (Nelson and quick, 2008). Also, in international research, five broad categories were found that cause teacher absenteeism including working condition, management, social and cultural responsibilities and community conditions. (Mary et al., 2015).

Extent research have examined the causes of teacher absenteeism. They found that low salary is one of the causes that is barrier to fulfill their life goals and teachers are not satisfied from it. Lack of basic health means also causes the teacher absenteeism; it shows that lack of food and access to a hospital and shortage of clean water compels teacher to make absence and results in sickness and disease (Tao, 2013). Furthermore, lack of motivation is another cause of teacher absenteeism. Professional development opportunities were reduced due to 
lack of motivation for teachers. Women are forced by patriarchal division of labor and expectations to be primary caregivers and housekeepers. Actual opportunities to advance school policies are not reflected, which mentions that men and women have equal opportunities to advance them. Female teachers mostly have less time to study the certification exam and perform poorly because of domestic obligations; this may lead teacher to higher absence rate (Tao, 2013).

Usman and Suryadarma (2007) studied Indonesian teachers' absenteeism and found that headmasters and highly educated teachers missed school days more than grade teachers (such as teachers who teach subjects other than physical education and religion). Extra jobs availability and opportunities outside of the schools were not found significant factor in teacher absence rates for highly educated teachers. Because of low control of District Education Office headmaster had high absenteeism rates than grade level teachers (Usman and Suryadarma, 2007). in addition, Illness was mentioned as cause of absenteeism of teachers in Malawi. In an HIV/AIDS study personal sickness, funeral attendance and attending sick family members considered the reason of teacher absenteeism (Kadzamira, 2006). Although teachers with some health problems might still attend work, some problems affect the ability of the teacher to carry the learning process. For example, a study was conducted on voice problem in United States, and found that 3.35\% of female teachers were absent due to voice problem (Medeiros et al., 2011).

Attending workshops and meetings caused teacher absenteeism in the Pacific Region which hurdles teacher to plan and fulfill professional development opportunities and other professional duties (Uehara, 1999). According to study conducted in Indonesia by Muralidharan and Sundararaman (2013) found that contract teachers were mostly absent than non-contract teachers. Contract teachers were appointed on agreement by local school were less trained and paid less. acquiring permanent teaching positions are also low for contract teachers (Usman \& Suryadarma, 2007). Moreover, structuring a school with multigrade classrooms results higher teacher absenteeism. Teachers in India and Indonesia were more likely to be absent in schools where multigrade teaching took place. Teachers were in stress due to multigrade classroom (Usman and Suryadarma, 2007). Poor work conditions are another cause to increase teacher absenteeism rates in different areas (Ngimbudzi, 2009). Such conditions include poor quality or inadequate school infrastructure such as teachers' offices, classrooms, furniture and toilets. In rural areas where decent accommodation is a challenge, lack of teacher housing forces teachers to leave far away from the school. In addition, locations of some schools are such that there is no restaurant or food delivery services in the school vicinity. As a result, lack of staff lunch might cause some teachers to skip work (Okurut, 2012; Al-Hassan, 2009; Alcazar et al., 2006).

\subsection{Effects of Teacher Absenteeism on Student Academic Achievement}

Teacher absenteeism is a growing and key challenge in schools negatively affecting quality education. A teacher in the classroom is an important but insufficient prerequisite for improving learning achievement. However, absenteeism significantly influences the learning outcomes of the children in the classroom.

The learning passion of students in classroom ultimately consumes when a teacher makes days off on regular basis; teacher absenteeism impacts (Bruno 2002). Replacement of absent teacher is different in urban schools. Teacher, who is substituted, is not always able to the usual classroom teacher's routine although, instructional methods do not encourage students to take interest in learning (Darling-Hammond, 1995; St. Michel, 1995). Further research was conducted that students' behavior and class performance disturb when they have to fit themselves with new teacher as compare to previous teacher because substitute teacher is not able to teach effectively. Furthermore, the regular teacher cannot concentrate on their instruction when she is substituted with an unqualified teacher and it causes the low concentration and energy of students towards learning as they do with their regular teacher (Elliot \& Manlove, 1977). Because of teacher absenteeism the regular activities and procedures of school and classroom are disturbed e.g. discontinuities of instructions may affect the student achievement. Teacher absenteeism and poor attitude slow the student academic progress and the relationship of student and teacher would be weakening when absence of teacher is high and cause student absenteeism as well; for instance, when student get absent frequently from school and asked why they do not go to school in response that his teacher also makes day off (Jacobson, 1989). According to Ehrenberg et al. (1991) high rate of teacher absenteeism discourage student to attend classes and impacts on student regularity in school. It was proved that urban teacher did not care the problem of teacher absenteeism while this study shows that only $1.6 \%$ teachers accept that teacher absenteeism interferes student performance (national data from the United States Bureau of Labor Statistics, 1996).

A study by Miller (2012) shows that teacher has the most important role to the academic success of students but teachers, who make absences frequently are not able to transfer the quality of education. Colleagues have to bear the work burden of their fellow teachers who are often absent then trust and harmony among staff is decreased. In Indonesia, the teachers who teach subjects have low teacher absenteeism rate as compare to high qualified teachers who deliver the physical and regional education. Extra job opportunities were not available for high educators and headmasters had the high rate of absenteeism due to insufficient guidance (Usman \& 
Suryadarma, 2007). Furthermore, teacher absenteeism causes wastage of public and private resources and significantly damages the system of school (Miller 2012). Das et al. (2005) reported that when a teacher had the same class for two years it increased $5 \%$ of teacher absence rate and reduced the learning level of students by 4 $8 \%$ in that duration. This study demonstrated that regular absence of classroom teacher had slowed and stopped the academic growth of students and they lost time in playing in order to learn (Darling-Hammond, 1995). Yiga and Wandega (2010) reported that $80 \%$ of students responded that their syllabus remained incomplete due to teacher absence and resulted in low grades (Yiga and Wandega, 2010). In addition, teacher attendance is as important as student attendance. If teacher misses the school a day, substitute teacher is directly affects student achievement. Teacher absenteeism does not only affect learning level of students but also disturbs the overall running building including people in school.

In developing countries, many researchers observed that high rate of teacher absenteeism is hurdle to impart education. Absence of teacher is a serious issue to improve education system effectively in a country. Similarly, the negative bond of teacher absenteeism and students' achievement (Bayard, 2003; Manatt, 1987; Sankale, 2014). When teacher makes days off over $7.5 \%$, highly affects the students' achievement (Mdden, Flanigan, Richardson, 1991). The increase rate of teacher absenteeism is high in rural area as compare to urban schools of Pakistan; most of the teachers may have troubles due to lack of training (World Bank Report, 2015). Teacher absenteeism is very common problem and affecting the student achievement (Barbara Knapp and Gene, 2004). A research conducted in Nepal Karnali and Gandaki shows that $18 \%$ teacher were absent from school while $21 \%$ was present but they were out of the class during lecture (Narhari et al, 1971). Another study was conducted that teacher absenteeism negatively affected the students' achievement; the high rate of teacher absenteeism could decrease the level of student performance (Uehara, 1999). Similarly, in Indonesia, it was researched that when teacher makes more days off the interest of students decrease in mathematics and get the low scores as well as the reading power cannot improve well (Suryadarma et al., 2006). Clotfelter, Ladd and Vigor argued (2007) that absences of teacher in classroom lessen the learning opportunities of students; furthermore, it was stated that teacher absenteeism reduced the math test score.

Another study investigated the Nigerian teachers' absenteeism, found that teacher absenteeism rate was found low and high rate of teaching activity was high in private schools rather than public schools (Tooley, Dixon, \& Olaniyan, 2005); in same year another study was conducted by National Bureau of Economics that to qualities school system was hard until reduced teacher absenteeism from developing countries. Ehrenberg et al. (1991 relevant research also shows that when teacher is absent regularly from school can negatively impact the students' performance. Moreover, the more absence of teacher from the classroom causes the students to get low score in every test. Another study was conducted in Nigeria that teacher absenteeism is broad issue which negates the goal which was set for improvement almost $20 \%$ of teaching staff was absent without having permission in Nigeria (World Bank, 2010). Ehrenberg et al. (1991) reported that teacher absenteeism directly affects the quality of instruction and results in low performance of schools.

If teacher makes regular absence the negative impression goes to students and society regarding teachers, relationship among staff can be disturbed and cause the negative school working environment. Similarly, quality of education, student academic success as well as the implementation of teaching plan in class have been interrupted (Hassan, 2009). Comparing both developed and developing countries, teacher absenteeism rate is high in developing countries. In India the study was conducted on primary education that shows when 226 Schools were visited so the one-third principles were on their duty whereas, $17 \%$ teachers were absent from schools and 20\% were not in class during the visit of schools. Another study was conducted in India that absenteeism is equal among the old teachers, qualified teachers and head teachers (Chaudhury et al., 2004). As compared to developing countries, developed countries' rate of teacher absenteeism is low, estimated rate of absenteeism is between 6-8\% (Bowers, 2001; Bradley, Green \& Levee, 2007).

Pakistan is a developing country and its place is 113 th among 120 countries and literacy rate is only $57 \%$ (Bejwa, 2011). Also Pakistan is one of them where the issue of teacher absenteeism is increasing day by day. Mostly, teacher absenteeism is hurdle in rural schools of country. Ghuman and Lioyd (2010) found that the female absenteeism rate is greater than male teachers in Pakistan. In government schools $17 \%$ of boys and $25 \%$ of girls had the problem of teachers' absence and also examined that local community appointed teachers do the less absence as compare to those teachers who come from outside (Ghuman \& Lioyd, 2010) Many causes of teacher absenteeism have been explored in Pakistan's schools like political interference, job safety, lack of social accountability and teacher unions (Harris, 2009).

According to Annual Status of Education Report (2015), in Pakistan, 11\% teachers make the day off from the classroom negates the quality of education and student future which they receive from absent teachers. Such environment is harmful for students where teachers are not interested and difficult to inspire students. Due to teacher absenteeism less learning occurs and students are discouraged to attend the school that is why student academic performance affected negatively and obtained poor scores on tests. Similarly, Hasnain (2008) concluded that less accountability and check and balance are so weak in the system which cause the teacher 
absenteeism in Pakistan. Lack of motivation and incentives, and low wages which are not sufficient to fulfill their family needs as well as less incentives to teachers reduce the teaching interest, are considered the reason that cause teacher absenteeism in schools.

\section{Research Methodology}

Research methodology is the specific procedure or techniques used to identify, select, process and analyze information about a topic. In a research paper, the methodology section allows the readers to critically evaluate a study's over all reliability and validity. The purpose of this study was to identify the causes and effects of teacher absenteeism on school students' academic achievement in Winder Tehsil Sonmiani District Lasbela, Balochistan.

\subsection{Research Nature and Design}

The research design identifies the three processes of research the selection of the respondents, plan about data collection and data analysis. This research paper was basically descriptive and inferential in nature. The quantitative method of research was used and non-probability sampling was applied to determine the sample size in order to collect evidences to attend the research objectives.

\subsection{Sampling and Data Collection of the Study}

The population is the summation of all entitles having characteristics of interest. The targeted population of the study included the all individuals of the five primary school of Winder, Lasbela Balochistan. The sampling scheme was used to collect the information about causes and effects of teacher absenteeism from teachers, students and parents by applying simple convenience sampling method in the 6 government primary school of Tehsil Winder.

This research paper is basically descriptive in nature, conducted in Winder, Lasbela Balochistan, Pakistan. The quantitative research method was used for collection of data through self-administered questionnaire.

Table 1 Demographic Characteristics of Participants

\begin{tabular}{|c|c|c|c|c|c|}
\hline Teachers & Percentage & Students & Percentage & Parents & Percentage \\
\hline Gender & & Gender & & Gender & \\
\hline Male & $30 \%$ & Male & $23 \%$ & Male & $70 \%$ \\
\hline Female & $70 \%$ & Female & $77 \%$ & Female & $30 \%$ \\
\hline Age & & Age & & Age & \\
\hline $25-30$ & $50 \%$ & $9-11$ & $44 \%$ & $25-30$ years & $40 \%$ \\
\hline $31-40$ & $20 \%$ & $12-13$ & $56 \%$ & $31-40$ years & $25 \%$ \\
\hline $41-50$ & $30 \%$ & & & $45-50$ years & $25 \%$ \\
\hline Designation & & Class/grade & & & \\
\hline JVT & $90 \%$ & $4^{\text {th }}$ & $33 \%$ & & \\
\hline JET & $10 \%$ & $5^{\text {th }}$ & $67 \%$ & $50-65$ years & $10 \%$ \\
\hline Experience & & Father occupation & & Qualification & \\
\hline $1-5$ & $40 \%$ & Employed & $46 \%$ & Matriculation & $35 \%$ \\
\hline $6-10$ & $10 \%$ & Unemployed & $20 \%$ & Intermediate & $35 \%$ \\
\hline $11-15$ & $40 \%$ & Farmer & $14 \%$ & Bachelor & $30 \%$ \\
\hline 16 and above & $10 \%$ & Other & $20 \%$ & & \\
\hline
\end{tabular}

\subsection{Validity and Reliability of Instruments}

The degree to which the result of a measurement, calculation, or specification can be depended on to be accurate. Cronbach's alpha is a measure of internal consistency, that is, how closely related a set of items are as a group. It is considered to be a measure of scale reliability. The alpha coefficient for the 20 items of Teachers' questionnaire was .723, suggesting that the items had relatively high internal consistency. Moreover, the alpha coefficient for the 20 items of Students' questionnaire was .701 and for the 20 items of Parent's questionnaire was .701 , suggesting that the items had relatively high internal consistency.

\subsection{Demographic Characteristics of Participants}

Table 1 shows that $30 \%$ of teacher respondents were male, $70 \%$ of the respondents were female. In terms of age $50 \%$ of respondents aged $25-30,20 \%$ age of teacher respondents was $31-40$, while $30 \%$ age of respondent was 45-50. $90 \%$ of respondents were serving as JVT and 10\% as JET respectively. Regarding teaching experience of respondents, $40 \%$ teacher respondents had experience of 5-7 years, $10 \%$ had $8-14$ year teaching experience, whereas, $40 \%$ had $20-25$ year and only $10 \%$ of respondents' teaching experience was $25-30$.

Table 1 displays that $77 \%$ of student respondents were female and $23 \%$ were male. In addition, student respondents had different characteristics in terms of age, class, and father occupation (see Table 1). 46\% of 
student respondents' father were employed, $20 \%$ were unemployed, while $14 \%$ were farmer, and $20 \%$ were others.

\section{Results and Discussion}

The empirical findings of the study are presented and discussed. Specifically, it deals with causes of teacher absenteeism and its impact on student achievement and the suggested solutions to curb teacher absenteeism in the study area. These aspects are presented according to each research objective.

Table 2 shows that $40 \%$ and $50 \%$ of teacher respondents reported that teachers regularly come to school, whereas $10 \%$ responded neutral. Suggesting that most of the respondents agreed and few responded. Consequently, teachers were regular in schools. Furthermore, statement teacher performs other jobs/business expect teaching where $20 \%$ strongly agreed, $10 \%$ agreed, $70 \%$ respondents are neutral with the statement. According to data majority of the respondents are neutral and few agreed. Thus, suggesting teacher perform other jobs other than teaching. Additionally, convenience is provided to teacher far flung areas in which $11 \%$ respondents strongly agreed, while 10\% agreed, $70 \%$ responded neutral whereas the $10 \%$ disagreed with statement. According to data, majority of teachers responded neutral and minority agreed. Hence, transport is rarely provided to teachers for far flung areas.

Table 2 Teacher's Opinion about Teacher Absenteeism

\begin{tabular}{|c|c|c|c|c|c|c|}
\hline S.No & Statements & SA & $\mathbf{A}$ & $\mathbf{N}$ & $\mathbf{D}$ & SA \\
\hline 1 & Teacher regularly comes to school. & $40 \%$ & $50 \%$ & $10 \%$ & $0 \%$ & $0 \%$ \\
\hline 2 & Teacher performs other jobs/business expect teaching & $20 \%$ & $10 \%$ & $70 \%$ & $0 \%$ & $0 \%$ \\
\hline 3 & Transport/convenience is provided to teacher for far flung areas. & $10.5 \%$ & $10.3 \%$ & $70 \%$ & $10 \%$ & $0 \%$ \\
\hline 4 & Teachers conduct class regularly on time & $20 \%$ & $60 \%$ & $10 \%$ & $10 \%$ & $0 \%$ \\
\hline 5 & Teachers have safety in school. & $10 \%$ & $70 \%$ & $20 \%$ & $0 \%$ & $0 \%$ \\
\hline
\end{tabular}

As shown in Table 2 , teachers conduct class regularly on. time indicates that $20 \%$ respondents strongly agreed, $60 \%$ agreed although, 10\% responded neutral and 10\% disagreed with the statement. According to data most of the people agreed strongly and minority of respondents disagreed. Concluding this, teachers regularly conduct class on time. While, with last statement of above table $10 \%$ respondents strongly agreed, $70 \%$ agreed and $20 \%$ responded neutral that teacher have safety in school. According to data majority of respondents agreed that teachers have safety in schools and minority of responded neutral. Thus, teachers have safety in schools.

Table 3 Teachers' Opinion about Causes of Teacher Absenteeism

\begin{tabular}{|c|c|c|c|c|c|c|}
\hline S.No & Statement & SA & $\mathbf{A}$ & $\mathbf{N}$ & $\mathbf{D}$ & SD \\
\hline 6 & Health challenges force teacher to make absence & $50 \%$ & $50 \%$ & $0 \%$ & $0 \%$ & $0 \%$ \\
\hline 7 & Teacher is less experienced and dissatisfied of job. & $10 \%$ & $20 \%$ & $70 \%$ & $0 \%$ & $0 \%$ \\
\hline 8 & Poor working conditions influence teacher to make absence. & $10.5 \%$ & $20 \%$ & $50 \%$ & $20 \%$ & $0 \%$ \\
\hline 9 & Teachers are less paid and unmotivated to work more & $10 \%$ & $20 \%$ & $70 \%$ & $0 \%$ & $0 \%$ \\
\hline 10 & Teachers often attend social functions. & $10 \%$ & $80 \%$ & $10 \%$ & $0 \%$ & $0 \%$ \\
\hline
\end{tabular}

Table 3 displays that the causes of teacher absenteeism in which the statement health challenges force teacher to make absence, shows that 50\% respondents strongly agreed and similarly 50\% agreed. Hence, health challenges result in teacher absenteeism. In addition, $10 \%$ respondents strongly agreed that teacher is less experienced and dissatisfied of job, whereas $20 \%$ agreed and $70 \%$ responded neutral. According to data majority of the respondents were neutral and minority agreed. Thus, less experience and dissatisfaction of job is the cause of teacher absenteeism. Moreover, poor working conditions is the cause of teacher absenteeism with this statement $10 \%$ strongly agreed, $20 \%$ respondents agreed whereas, $50 \%$ responded neutral and $20 \%$ disagreed that poor working conditions influence teacher to make absence. According to data most of the respondents were neutral. Therefore, poor working conditions force teacher to make absence. In addition, teachers are less paid and unmotivated to work more in which $10 \%$ strongly agreed, $20 \%$ agreed and $70 \%$ respondents were neutral with statement so majority of respondents were neutral therefore, less payment and motivation to work more for teachers cause teacher absenteeism. The statement teachers often attend social functions in which $10 \%$ strongly agreed, $80 \%$ agreed and $10 \%$ responded neutral. According to data majority of the teachers agreed and minority was neutral with statement. Hence, attending social functions cause teacher absenteeism.

Table 4 Teachers' Opinion about Practices to Control Teacher Absenteeism

\begin{tabular}{|c|c|c|c|c|c|c|}
\hline S.No & Statement & SA & $\mathbf{A}$ & $\mathbf{N}$ & $\mathbf{D}$ & SD \\
\hline 11 & $\begin{array}{l}\text { Proper monitoring system is provided by government for the } \\
\text { accountability of teachers }\end{array}$ & $20 \%$ & $60 \%$ & $20 \%$ & $0 \%$ & $0 \%$ \\
\hline 12 & $\begin{array}{l}\text { Teachers are guided and counseled to deal with the challenges } \\
\text { of absenteeism. }\end{array}$ & $70 \%$ & $10 \%$ & $20 \%$ & $0 \%$ & $0 \%$ \\
\hline 13 & Teachers are paid more for extra performance. & $10 \%$ & $70 \%$ & $20 \%$ & $0 \%$ & $0 \%$ \\
\hline 14 & Teachers are awarded monetary and non-monetary incentives & $10 \%$ & $40 \%$ & $50 \%$ & $0 \%$ & $0 \%$ \\
\hline 15 & Teachers are restricted to do job actively. & $10 \%$ & $70 \%$ & $10 \%$ & $10 \%$ & $0 \%$ \\
\hline
\end{tabular}


Table 4 demonstrates that the practices to control teacher absenteeism in which statement proper monitoring system is provided by government for the accountability of teachers show that $20 \%$ strongly agreed, $60 \%$ agreed and $20 \%$ respondents were not supporting the statement. According to data large part of respondents agreed and minority was neutral with statement. Thus, it is stated that teachers are monitored properly for accountability. Furthermore, in the second statement teachers are guided and counseled to deal with the challenges of absenteeism $70 \%$ respondents strongly agreed, 10\% agreed and 20\% responded neutral. According to data majority of respondents strongly agreed and very less responded neutral. Therefore, teachers are guided and counseled to control teacher absenteeism. Moreover, teachers are paid more for extra performance in which $10 \%$ strongly agreed, $70 \%$ agreed while, $20 \%$ neutral so the data shows that majority of respondents agreed and minority respondents were not supporting the statement. Thus, teacher absenteeism may control if more is paid to teacher for extra performance.

Furthermore, $10 \%$ respondents strongly agreed, $40 \%$ agreed with the statement that teachers are awarded monetary and non-monetary incentives in respectively and $50 \%$ responded neutral. According to data monetary and non-monetary incentives for teacher can reduce teacher absenteeism. Besides, teachers are restricted to do job actively in this statement 10\% respondents strongly agreed, $70 \%$ agreed, $10 \%$ responded neutrally and $10 \%$ disagreed with statement. According to data majority was agree and minority disagreed with statement. Hence, teachers should be restricted in order to do job actively.

Table 5 Teachers' Opinion about Effects of Absenteeism

\begin{tabular}{|c|c|c|c|c|c|c|}
\hline S.No & Statements & SA & $\mathbf{A}$ & $\mathbf{N}$ & D & SD \\
\hline 16 & Irregularity of teacher affects quality Education of school. & $40 \%$ & $60 \%$ & $0 \%$ & $0 \%$ & $0 \%$ \\
\hline 17 & Instructional hours are cut and syllabus remained incomplete & $80 \%$ & $10 \%$ & $10 \%$ & $0 \%$ & $0 \%$ \\
\hline 18 & Student class activities are disturbed & $40 \%$ & $10 \%$ & $50 \%$ & $0 \%$ & $0 \%$ \\
\hline 19 & Student class activities are disturbed & $40 \%$ & $10 \%$ & $50 \%$ & $0 \%$ & $0 \%$ \\
\hline 20 & Student performance is significantly affected in a negative way. & $20 \%$ & $70 \%$ & $10 \%$ & $0 \%$ & $0 \%$ \\
\hline
\end{tabular}

Table 5 shows that the impact of teacher absenteeism on student achievements in which first statement irregularity of teacher affects quality education of school $40 \%$ strongly agree, $60 \%$ agreed with statement. Therefore, quality education of school is affected by irregularity of teachers. Besides, Instructional hours are cut and syllabus remained incomplete in this statement $80 \%$ respondents strongly agreed, $10 \%$ agreed while $10 \%$ responded neutrally. According to data majority responded that instructional hours are cut and syllabus remained incomplete and less were disagreed with statement. Hence, if teachers miss class time is wasted and syllabus remained incomplete. Next statement Student class activities are disturbed in which 40\% strongly agreed, $10 \%$ agreed and 50\% responded neutrally. Thus, student class activities are disturbed due to teacher absenteeism. On last statement Student performance is significantly affected in a negative way $20 \%$ strongly agreed, $70 \%$ agreed and $10 \%$ respondents were neutral. According to data majority agreed with statement and minority responded neutral. Therefore, student performance is affected negatively.

Table 6 Students' Opinion on Teacher Absenteeism

\begin{tabular}{|c|c|c|c|c|c|c|}
\hline S.No & Statements & SA & $\mathbf{A}$ & $\mathbf{N}$ & $\mathbf{D}$ & SD \\
\hline 1 & Teacher regularly comes to school. & $43 \%$ & $43 \%$ & $7 \%$ & $7 \%$ & $0 \%$ \\
\hline 2 & Teacher performs other jobs/business expect teaching & $3 \%$ & $13 \%$ & $47 \%$ & $17 \%$ & $20 \%$ \\
\hline 4 & Transport/convenience is provided to teacher for far flung areas & $10 \%$ & $20 \%$ & $20 \%$ & $23 \%$ & $27 \%$ \\
\hline 5 & Teachers have safety in school. & $27 \%$ & $30 \%$ & $10 \%$ & $13 \%$ & $20 \%$ \\
\hline
\end{tabular}

Table 6 depicts that teacher absenteeism in which the first statement teacher regularly comes to school $43 \%$ strongly agreed, 43\% agreed, 7\% responded neutral and 7\% disagreed. According to data most of the respondents agreed and minority disagreed. Consequently, teachers were regular in schools. Furthermore, statement teacher performs other jobs/business expect teaching where 3\% strongly agreed, 13\% agreed, $47 \%$ respondents are neutral and $17 \%$ disagreed while $20 \%$ strongly disagreed with the statement. According to data majority of the respondents are neutral and minority disagreed. Thus, teacher perform other jobs expect teaching. Additionally, above 3rd statement transport/ convenience is provided to teacher for flung areas in which $10 \%$ respondents strongly agreed, while $20 \%$ agreed, $20 \%$ responded neutral whereas the $23 \%$ disagreed and $27 \%$ disagreed with statement. According o data majority disagreed and minority agreed. Hence, transport is rarely provided to teachers for far flung areas. Moreover, with last statement of above table Teachers have safety in school $27 \% \%$ respondents strongly agreed, $70 \%$ agreed and $20 \%$ responded neutral that teacher have safety in school. According to data majority of respondents agreed that teachers have safety in schools and minority of responded neutral. Thus, teachers have safety in schools. 
Table 7 Student's Opinion about Causes of Teacher Absenteeism

\begin{tabular}{|c|c|c|c|c|c|c|}
\hline S.No & Statements & SA & $\mathbf{A}$ & $\mathbf{N}$ & D & SD \\
\hline 6 & Health challenges force teacher to make absence & $33 \%$ & $7 \%$ & $5 \%$ & $20 \%$ & $35 \%$ \\
\hline 7 & Teacher is less experienced and dissatisfied of job & $7 \%$ & $20 \%$ & $33 \%$ & $20 \%$ & $20 \%$ \\
\hline 8 & Poor working conditions influence teacher to make absence. & $7 \%$ & $33 \%$ & $37 \%$ & $20 \%$ & $3 \%$ \\
\hline 9 & Teachers are less paid and unmotivated to work more & $3 \%$ & $33 \%$ & $13 \%$ & $34 \%$ & $16.7 \%$ \\
\hline 10 & Teacher often attend social functions. & $6.7 \%$ & $20 \%$ & $33 \%$ & $16.7 \%$ & $23 \%$ \\
\hline
\end{tabular}

Table 6 shows that the causes of teacher absenteeism in which the statement health challenges force teacher to make absence shows that 33\% respondents strongly agreed and 7\% agreed, 5\% responded neutral, $20 \%$ disagreed and $35 \%$ respondents strongly disagreed. Hence, health challenges result in teacher absenteeism. In addition, $7 \%$ respondents strongly agreed that teacher is less experienced and dissatisfied of job, whereas $20 \%$ agreed and 33\% responded neutral, 20\% disagreed with statement and 20\% strongly disagreed. According to data majority of the respondents were disagree and minority neutral. Therefore, less experience and dissatisfaction of job is the cause of teacher absenteeism. Moreover, poor working conditions is the cause of teacher absenteeism with this statement 7\% strongly agreed, 33\% respondents agreed whereas 37\% $\%$ responded neutral and $20 \%$ disagreed that poor working conditions influence teacher to make absence and $3 \%$ strongly disagreed. According to data most of the respondents agreed and minority was neutral. However, poor working conditions force teacher to make absence. Additionally, respondents asked that teachers are less paid and unmotivated to work more in which 3\% strongly agreed, 33\% agreed and 13\% respondents were neutral with statement whereas $34 \%$ disagreed and $17 \%$ strongly disagreed so majority of respondents were disagreed and less were agree. Therefore, less payment and motivation to work more for teachers cause teacher absenteeism. The statement teachers often attend social functions in which 7\% strongly agreed, 20\% agreed and 33\% responded neutral, $17 \%$ disagreed and 23\% strongly disagreed. According to data majority of the teachers disagreed and minority was neutral with statement. Hence, attending social functions cause teacher absenteeism.

Table 8 Student's Opinion about Practices to Control Teacher Absenteeism

\begin{tabular}{|c|c|c|c|c|c|c|}
\hline S.No & Statements & $\mathbf{S A}$ & $\mathbf{A}$ & $\mathbf{N}$ & D & SD \\
\hline 11 & $\begin{array}{l}\text { Proper monitoring system is provided by government } \\
\text { for the accountability of teachers }\end{array}$ & $30 \%$ & $23 \%$ & $16.7 \%$ & $20 \%$ & $10 \%$ \\
\hline 12 & $\begin{array}{l}\text { Teachers are guided and counseled to deal with the } \\
\text { challenges of absenteeism. }\end{array}$ & $6.7 \%$ & $40 \%$ & $40 \%$ & $13 \%$ & $0 \%$ \\
\hline 13 & Teachers are paid more for extra performance & $3 \%$ & $26.7 \%$ & $23 \%$ & $26.7 \%$ & $20 \%$ \\
\hline 14 & $\begin{array}{l}\text { Teachers are awarded monetary and non-monetary } \\
\text { incentives }\end{array}$ & $3 \%$ & $16.7 \%$ & $26.7 \%$ & $23 \%$ & $30 \%$ \\
\hline 15 & Teachers are restricted to do job actively. & $13 \%$ & $30 \%$ & $23 \%$ & $23 \%$ & $10 \%$ \\
\hline
\end{tabular}

As displayed in Table 8, student respondents asked that proper monitoring system is provided by government for the accountability of teachers showed that $30 \%$ strongly agreed, $23 \%$ agreed, $17 \%$ respondents were not supporting the statement, $20 \%$ disagreed and $10 \%$ strongly disagreed. According to data large part of respondents agreed and minority was disagreed with statement. Thus, it is stated that teachers are monitored properly for accountability. Furthermore, teachers are guided and counseled to deal with the challenges of absenteeism $7 \% \%$ respondents strongly agreed, $40 \%$ agreed and $40 \%$ responded neutral, $13 \%$ disagreed. According to data majority of respondents strongly agreed and very less responded neutral. Therefore, teachers are guided and counseled to control teacher absenteeism. Further, teachers are paid more for extra performance in which $3 \%$ strongly agreed, $27 \%$ agreed while, $23 \%$ neutral, $27 \%$ disagreed and $20 \%$ strongly disagreed so the data shows that majority of respondents disagreed and minority respondents were not supporting the statement. Thus, teacher absenteeism may control if more is paid to teacher for extra performance.

Table 8 also explains that student respondents reported that teachers are awarded monetary and nonmonetary incentives in which 3\% respondents strongly agreed 17\% agreed and $27 \%$ responded neutral, $23 \%$ respondents disagreed and $30 \%$ strongly disagreed. According to data majority of respondents disagreed and minority responded neutral. Thus, monetary and non-monetary incentives for teacher can reduce teacher absenteeism. Besides, teachers are restricted to do job actively in this statement $13 \%$ respondents strongly agreed, $30 \%$ agreed, $23 \%$ responded neutrally and $23 \%$ disagreed with statement, $10 \%$. According to data majority was agree and minority disagreed with statement. Hence, teachers should be restricted in order to do job actively. 
Table 9 Student's Opinion about Effects of Teacher Absenteeism

\begin{tabular}{|c|c|c|c|c|c|c|}
\hline S.No & Statements & SA & $\mathbf{A}$ & $\mathbf{N}$ & D & SD \\
\hline 16 & Irregularity of teacher affects quality Education of school. & $70 \%$ & 16.7 & $10 \%$ & 3.3 & $0 \%$ \\
\hline 17 & Instructional hours are cut and syllabus remained incomplete & $10 \%$ & $60 \%$ & 6.7 & 16.7 & 6.7 \\
\hline 18 & Pupils become unable to proceed to the next level education & 23.3 & 43.3 & $20 \%$ & 3.3 & $10 \%$ \\
\hline 19 & Student performance is significantly impacted in a negative way. & $30 \%$ & 36.7 & 16.7 & 16.7 & $0 \%$ \\
\hline 20 & Student class activities are disturbed. & $10 \%$ & 43.3 & $20 \%$ & 13.3 & 13.3 \\
\hline
\end{tabular}

As demonstrated in Table 9, student participants responded regarding the effects of teacher absenteeism on student achievements in which irregularity of teacher affects quality education of school $70 \%$ strongly agreed, $17 \%$ disagreed, $10 \%$ responded neutral, $3 \%$ disagreed with statement. Therefore, quality education of school is affected by irregularity of teachers. Besides, Instructional hours are cut and syllabus remained incomplete in this statement $10 \%$ respondents strongly agreed, $60 \%$ agreed while $7 \%$ responded neutrally, $17 \%$ disagreed and $7 \%$ strongly disagreed. According to data majority responded that instructional hours are cut and syllabus remained incomplete and less were disagreed with statement. Hence, if teachers miss class time is wasted and syllabus remained incomplete. Next statement Pupils become unable to proceed to the next level education in which $23 \% \%$ strongly agreed, $43 \%$ agreed, $20 \%$ responded neutrally, 3\% disagreed and 10\% strongly disagreed. According to data majority of respondents agreed and minority responded neutrally. Hence, teacher absenteeism makes students unable to continue next level education. On statement Student performance is significantly impacted in a negative way $30 \%$ strongly agreed, $37 \%$ agreed while $17 \%$ responded neutrally, $17 \%$ disagreed with statement. According to data majority of respondents agreed with statement. Hence student performance is affected negatively. On last statement Student performance is significantly affected in a negative way $20 \%$ strongly agreed, $70 \%$ agreed and 10\% respondents were neutral. According to data majority agreed with statement and minority responded neutral. Therefore, student performance is affected negatively. On last statement Student class activities are disturbed in which 10\% respondents strongly agreed, $43 \%$ agreed, whereas, $20 \%$ responded neutral and 13\% disagreed and 13\% strongly disagree with statement Thus, student class activities are disturbed due to teacher absenteeism.

Table 10 Parent's Opinion on Teacher Absenteeism

\begin{tabular}{|c|c|c|c|c|c|c|}
\hline S.No & Statements & $\mathbf{S A}$ & $\mathbf{A}$ & $\mathbf{N}$ & DA & SDA \\
\hline 1 & Teacher regularly comes to school. & $25 \%$ & $35 \%$ & $20 \%$ & $15 \%$ & $5 \%$ \\
\hline 2 & Teacher performs other jobs/business expect teaching & $5 \%$ & $10 \%$ & $30 \%$ & $50 \%$ & $5 \%$ \\
\hline 3 & Transport/ convenience is provided to teacher for far flung areas & $5 \%$ & $10 \%$ & $10 \%$ & $55 \%$ & $20 \%$ \\
\hline 4 & Teachers conduct class regularly on time & $10 \%$ & $55 \%$ & $20 \%$ & $15 \%$ & $0 \%$ \\
\hline 5 & Teachers have safety in school. & $10 \%$ & $40 \%$ & $35 \%$ & $5 \%$ & $10 \%$ \\
\hline
\end{tabular}

Table 10 describes the opinion of parent participants regarding teacher regularity in school and responded that $25 \%$ strongly agreed, $35 \%$ agreed, $20 \%$ responded neutral, 15\% disagreed with statement as $5 \%$ strongly disagreed that teacher comes to school regularly. According to data most of the respondents agreed and minority disagreed. Consequently, teachers were regular in schools. Furthermore, statement regarding teacher performs other jobs/business expect teaching where 5\% strongly agreed, 10\% agreed, 30\% respondents are neutral with the statement and 50\% disagreed whereas, $5 \%$ strongly agreed with statement. According to data majority of the respondents disagreed and minority agreed. Thus, teacher perform other jobs expect teaching. Additionally, above 3rd statement transport/ convenience is provided to teacher for flung areas in which $10 \%$ respondents strongly agreed, while $10 \%$ agreed, $10 \%$ responded neutral whereas the $55 \%$ disagreed with statement and $20 \%$ strongly disagreed. According to data majority disagreed and minority agreed. Hence, transport is rarely provided to teachers for far flung areas.

Moreover, statement about teachers conduct class regularly on time indicates that $10 \%$ respondents strongly agreed, 55\% agreed although, 20\% responded neutral and 15\% disagreed with statement. According to data most of the people agreed strongly and few of them were neutral. Concluding this, teachers regularly conduct class on time. While, with last statement of above table $10 \%$ respondents strongly agreed, $40 \%$ agreed and $35 \%$ responded neutral, 5\% disagreed and 10\% strongly disagreed that teacher have safety in school. According to data majority of respondents agreed that teachers have safety in schools and minority of responded neutral. Thus, teachers have safety in schools.

Table 11 Parent's Opinion about Causes of Teacher Absenteeism

\begin{tabular}{|c|c|c|c|c|c|c|}
\hline S.No & Statements & SA & $\mathbf{A}$ & $\mathbf{N}$ & D & SD \\
\hline 6 & Health challenges force teacher to make absence & $15 \%$ & $70 \%$ & $15 \%$ & $0 \%$ & $0 \%$ \\
\hline 7 & Teacher is less experienced and dissatisfied of job. & $5 \%$ & $25 \%$ & $15 \%$ & $45 \%$ & $10 \%$ \\
\hline 8 & Poor working conditions influence teacher to make absence. & $30 \%$ & $15 \%$ & $40 \%$ & $15 \%$ & $0 \%$ \\
\hline 9 & Teachers are less paid and unmotivated to work more & $10 \%$ & $10 \%$ & $20 \%$ & $40 \%$ & $20 \%$ \\
\hline 10 & Teachers often attend social functions & $10 \%$ & $25 \%$ & $40 \%$ & $15 \%$ & $10 \%$ \\
\hline
\end{tabular}

Table 11 presents that the causes of teacher absenteeism in which the statement regarding health challenges 
force teacher to make absence shows that $15 \%$ respondents strongly agreed and similarly $70 \%$ agreed, $15 \%$ responded neutral with statement. Hence, health challenges result in teacher absenteeism. In addition, 5\% respondents strongly agreed that teacher is less experienced and dissatisfied of job, whereas $25 \%$ agreed and $15 \%$ responded neutral, $45 \%$ disagreed and $10 \%$ strongly agreed. According to data majority of the respondents were disagree and minority agreed. Thus, less experience and dissatisfaction of job is the cause of teacher absenteeism. Moreover, poor working conditions is the cause of teacher absenteeism with this statement $30 \%$ strongly agreed, $15 \%$ respondents agreed whereas, $40 \%$ responded neutral and $15 \%$ disagreed that poor working conditions influence teacher to make absence. According to data most of the respondents agreed. Therefore, poor working conditions force teacher to make absence. In addition to next statement, teachers are less paid and unmotivated to work more in which $10 \%$ strongly agreed, $10 \%$ agreed and $20 \%$ respondents were neutral with statement, $40 \%$ disagreed and $20 \%$ strongly disagreed so majority of respondents disagreed therefore, less payment and motivation to work more for teachers cause teacher absenteeism. The statement teachers often attend social functions in which $10 \%$ strongly agreed $25 \%$ agreed and $40 \%$ responded neutral, $15 \%$ disagreed and $10 \%$ strongly disagreed. According to data majority of the teachers were neutral and minority strongly agreed with statement. Hence, attending social functions cause teacher absenteeism.

Table 12 Parent's Opinion about Practices to Control Teacher Absenteeism

\begin{tabular}{|c|c|c|c|c|c|c|}
\hline S.No & Statements & SA & A & $\mathbf{N}$ & D & SD \\
\hline 11 & $\begin{array}{l}\text { Proper monitoring system is provided by government } \\
\text { for the accountability of teachers }\end{array}$ & $5 \%$ & $50 \%$ & $20 \%$ & $20 \%$ & $5 \%$ \\
\hline 12 & $\begin{array}{l}\text { Teachers are guided and counseled to deal with the } \\
\text { challenges of absenteeism. }\end{array}$ & $5 \%$ & $30 \%$ & $15 \%$ & $30 \%$ & $20 \%$ \\
\hline 13 & Teachers are paid more for extra performance & $10 \%$ & $20 \%$ & $45 \%$ & $25 \%$ & $0 \%$ \\
\hline 14 & $\begin{array}{l}\text { Teachers are awarded monetary and non-monetary } \\
\text { incentives }\end{array}$ & $5 \%$ & $10 \%$ & $35 \%$ & $40 \%$ & $10 \%$ \\
\hline 15 & Teachers are restricted to do job actively. & $10 \%$ & $30 \%$ & $5 \%$ & $30 \%$ & $25 \%$ \\
\hline
\end{tabular}

Table 12 presents parent respondents' opinion regarding provision of monitory system and majority of participants reported that 5\% strongly agreed, $50 \%$ agreed and $20 \%$ respondents were not supporting the statement. According to data large part of respondents agreed and minority was neutral with statement, $20 \%$ disagreed and 5\% strongly disagreed. According to data majority was agree with statement and minority disagreed. Thus, it is stated that teachers are monitored properly for accountability. Furthermore, in second statement teachers are guided and counseled to deal with the challenges of absenteeism $5 \%$ respondents strongly agreed, $30 \%$ agreed and $15 \%$ responded neutral, $30 \%$ disagreed and $20 \%$ strongly disagreed. According to data majority of respondents strongly agreed and very less responded neutral. Therefore, teachers are guided and counseled to control teacher absenteeism. Next, teachers are paid more for extra performance in which $10 \%$ strongly agreed, $20 \%$ agreed while, $45 \%$ neutral, $25 \%$ disagreed so the data shows that majority of respondents disagreed and minority respondents were not supporting the statement. Thus, teacher absenteeism may control if more is paid to teacher for extra performance.

Table 12 also presents that teachers are awarded monetary and non-monetary incentives in which $5 \%$ respondents strongly agreed, $10 \%$ agreed and 35\% responded neutral, $40 \%$ disagreed and $10 \%$ strongly disagreed. According to data monetary and non-monetary incentives for teacher can reduce teacher absenteeism. Besides, teachers are restricted to do job actively in this statement $10 \%$ respondents strongly agreed, $30 \%$ agreed, $5 \%$ responded neutrally and $30 \%$ disagreed with statement whereas, $25 \%$ strongly disagreed with statement. According to data majority was disagree and minority agreed with statement. Hence, teachers should be restricted in order to do job actively.

Table 13 Parent's Opinion about Effects of Teachers Absenteeism

\begin{tabular}{|c|c|c|c|c|c|c|}
\hline S.No & Statements & SA & $\mathbf{A}$ & $\mathbf{N}$ & D & SD \\
\hline 16 & Irregularity of teacher affects quality Education of school. & $70 \%$ & $25 \%$ & $5 \%$ & $0 \%$ & $0 \%$ \\
\hline 17 & d syllabus remained incomplete & $15 \%$ & $60 \%$ & $20 \%$ & $5 \%$ & $0 \%$ \\
\hline 18 & Student class activities are disturbed & $30 \%$ & $55 \%$ & $15 \%$ & $0 \%$ & $0 \%$ \\
\hline 19 & Pupils become unable to proceed to the next level education. & $25 \%$ & $50 \%$ & $20 \%$ & $5 \%$ & $0 \%$ \\
\hline 20 & Student performance is significantly impacted in a negative way. & $20 \%$ & $35 \%$ & $30 \%$ & $5 \%$ & $10 \%$ \\
\hline
\end{tabular}

Table 13 depicts that majority of respondents reported that teacher absenteeism affect students' academic achievement. The results show that irregularity of teacher affects quality education of school; $70 \%$ strongly agreed, $25 \%$ agreed with statement, $5 \%$ responded neutral. According to data majority strongly agreed and minority responded neutral. Therefore, quality education of school is affected by irregularity of teachers. Besides, Instructional hours are cut and syllabus remained incomplete in this statement $15 \%$ respondents strongly agreed, $60 \%$ agreed while $20 \%$ responded neutrally, $5 \%$ disagreed. According to data majority responded that instructional hours are cut and syllabus remained incomplete and less was disagreed with statement. Hence, if teachers miss class time is wasted and syllabus remained incomplete. Next statement Student class activities are 
disturbed in which $30 \%$ strongly agreed, $55 \%$ agreed and $15 \%$ responded neutrally. Thus, student class activities are disturbed due to teacher absenteeism. Statement Pupils become unable to proceed to the next level education in which $25 \%$ strongly agreed, 50\% agreed, 20\% responded neutral and 5\% disagreed. According to data majority agreed and minority of responded were neutral. Hence, teacher absenteeism makes pupils unable to continue next level education. Student performance is significantly affected in a negative way $20 \%$ strongly agreed, 35\% agreed and 30\% respondents were neutral, 5\% disagreed and 10\%. According to data majority agreed with statement and minority responded neutral. Therefore, student performance is affected negatively.

\section{Conclusion and Recommendations}

The findings of the study revealed that teacher absenteeism has significant negative impact on the students' academic achievement. teacher absenteeism affects student achievement, it is considered the most essential in each group of people that students class activities are disturbed if teacher is absence in class. as a matter of fact, teacher absenteeism is the cause of incomplete syllabus and reducing instructional hours. Furthermore, teacher absenteeism makes students unable to continue next level of education. It is suggested that teacher absenteeism could be reduced through managing late arrivals by way of extra pay instead of threats to sack people helps to ensure that junior teachers work in harmony with their superiors and this creates a corporate accord between teachers and superiors, which is a necessary ingredient for performance.

The findings revealed that teacher absenteeism is prevalent in the primary schools of district Lasbela and its rate has a greater influence on the performance of the student when the all other factor remaining constant. We conclude that teacher absenteeism is inversely related to student performance. It means higher teacher absenteeism rate having lower academic performance, and lower absenteeism teacher rate the higher student score. All teachers of government schools have been paid more than twenty thousand and no teachers receive less than ten thousand. This accounts for the poor performance of students in examination. The study also concludes that health challenges, teachers attending social functions, lack or inadequate accommodation facilities in communities, long distances, poor conditions of service, teachers going for further Studies, inadequate water supply and delay in mechanizing salaries of newly trained teachers are the factors that account for teacher absenteeism in the area. Furthermore, teacher absenteeism, as this work explains, is affecting educational quality. Teacher absenteeism is affecting student's achievements and also is affecting teachers performing. Policies are needed to reduce this behavior and motivate teachers to give them the confidence that they have a real impact on student achievements.

All staff member and school principal should be aware of the content of result how serious issue teacher absenteeism has, most of the student already depressed in many other ways and they want proper attention and focus from their teacher. The school principal should always be contacted with the teacher individual on a daily basis those are absent from school. The researcher had concluded that most effective way of reducing the teacher absenteeism to apply a requiring policy in which teacher directly contact with the principal when they are sick (Keller, 2008). Beware of this issue is a burden on the principal; their efficiency of method will reduce the effort and help to improve the teacher attendance.

It ultimately assists in reducing the financial outflow of substitute teachers. It also provides more money for the principal to provide teacher incentive that will be helpful in high attendance. In some condition when the principal does not contact with the teacher when they are out from the school, it is implausible that they will be aware of the teacher when he is absent on a regular basis. In a start of every year, principal should explain all teachers and staff attendance and follow up to monitor presence. Every district monitoring in charge, must collect the data about leave usage of their employees. It is also recommended that implementation of encouraging incentive programmers, rewards to good attendance, such as cash payment at the spot for those teachers who were having a good presence or those people who do not use more leaves. School teachers should be recognized having good attendance or provide a better gift, such as a reward.

\section{References}

Ameeq, M., Hassan, M. M., Jabeen, M., \& Fatima, L. (2018). Impact of Teacher Absenteeism on Student Achievement: A Case of South Punjab District Muzaffargarh, Pakistan. Education, 9(16).

Clotfelter, C.T., Ladd, H.F., \& Vigdor, J.L. (2007). Are teacher absences worth worrying about in the U.S.? [NBER Working Paper No. 13648]. Retrieved from the National Bureau of Economics website: http://www.nber.org/papers/w13648

Ehrenberg, R.G., Ehrenberg, R.A., Rees, D.I., \& Ehrenberg. E.L. (1991). School district leaves policies, teacher absenteeism, and student achievement. The Journal of Human Resources, 26(1), 72-105.

Kadzamira, E. C. (2006). Teacher motivation and incentives in Malawi. (Access on 6th January 2016, from http://www.elides. org/vfile/upload 1 I document/07 09/Teacher motivationMalawi.pdf).

Kremer, M., Chaudhury, N., Rogers, F. H., Muralidharan, K. \& Hammer, J. (2005). Teacher absence in India: A snapshot. Journal of the European Economic Association, 3(2-3), 658-667. 
Kremer, K., Chaudhury, N., Rogers, F. H., Muralidharan, K., \& Hammer, J. (2005). Teacher absence in India: A snapshot. Journal of the European Economic Association, 3, 658-667.

Kuusiemeh, A. (2016). TEACHER ABSENTEEISM: EFFECTS ON PUPILS'ACADEMIC Darling-Hammond, L., \& St. Michel (1995). Inequality and access to knowledge:

Mary, L., Crystal, G., Nitara, D., Wendy, K. (2015). Review oj international research onfactors underlying teacher absenteeism (REL 2015-087). Washington, DC: U.S.

PROBE, T. (1980). The (1999): Public Report on Basic Education in India: New Delhi: Oxford Uni Scott, K.D., and McClellan, E.L. (1990) Gender difference in absenteeism. Public Personnel Management, 19(2):229 253.versity Press renal of the European Economic Association, 3, 658-667.

Sankale, O. (2014). Influence of government intervention measures on girl child completion of primary education in Mao Division, Narok county, Kenya (Doctoral dissertation).

Sezgin, F., Koşar, S., Kılınç, A. Ç. \& Öğdem, Z. (2014). Teacher Absenteeism in Turkish Primary Schools: A Qualitative Perspective from School Principals. International Online Journal of Educational Sciences, 6(3).

Scott, K.D., and McClellan, E.L. (1990) Gender difference in absenteeism. Public Personnel Management, 19(2):229 - 253.University Press.

Usman, S., \& Suryadarma, D. (2007). Patterns of teacher absence in public primary schools in Indonesia. Asia Pacific Journal of Education, 27(2), 207-219.

Tao, S. (2013). Why are teachers absent? Utilizing the capability approach and critical realism to explain teacher performance in Tanzania. International Journal of Educational Development 33(1),2-14. 